ALONA PROKOPENKO, PhD of Pedagogical Sciences, lecturer at the Department of Informatics Municipal Establishment "Kharkiv Humanitarian-Pedagogical Academy" of Kharkiv Regional Council Kharkiv, Ukraine ORCID ID 0000-0002-3735-342X

\title{
MODERN ASPECTS OF THE USE OF FOGGY TECHNOLOGIES IN THE EDUCATIONAL PROCESS OF HIGHER EDUCATIONAL INSTITUTIONS
}

\author{
АЛЬОНА ПРОКОПЕНКО, кандидат педагогічних наук, \\ викладач кафедри інформатики комунального закладу \\ «Харківська гуманітарно-педагогічна академія» \\ Харківської обласної ради м. Харків, Україна
}

\section{СУЧАСНІ АСПЕКТИ ВИКОРИСТАННЯ ТУМАННИХ ТЕХНОЛОГІЙ У ОСВІТНЬОМУ ПРОЦЕСІ ЗАКЛАДІВ ВИЩОЇ ОСВІТИ}

The article considers the issues of improving the managerial and educational activities of higher education institutions through the use of cloudy and foggy innovative technologies. The author of the article on the basis of the analysis of scientific, pedagogical and specialized literature proves the relevance of research in this direction. This scientific legacy presents Google services that are appropriate to use in the educational process to increase its effectiveness and efficiency, as well as the feasibility of organizing and implementing an educational and scientific laboratory of innovative technologies.

Key words: innovative technologies, cloud technologies, fog computing, fog technologies, educational process.

Анотація. У статті розглянуто питання удосконалення управлінської та освітньої діяльності закладів вищої освіти за допомогою використання хмарних та туманних інноваційних технологій. Автор статті на основі аналізу науково-педагогічної та спеціальної літератури доводить актуальність досліджень у даному напрямку. В даному науковому доробку представлено сервіси Google, які

(C) A. Prokopenko доцільно використовувати в освітньому процесі для підвищення його результативності та ефективності, а також обгрунтовано доцільність організації та впровадження освітньо-наукової лабораторії інноваційних технологій.

Ключові слова: інноваційні технології, хмарні технології, туманні обчислення, туманні технології, освітній процес.

One of the most important features of the present stage of modernization of all spheres of society is the development and design of distributed organizational and informational structures and common models of information systems whose purpose is the formation, content and organization of the use of information databases; preparation, publication and dissemination of national and international scientific, economic, technical and other information that will enhance the performance of organizations in General and departments in particular. Information support of managerial, economic, scientific, educational, technical and technological innovations for productive activities of the organization consists of innovation, marketing, social, economic and information processes.

In this case, the success and effectiveness of organizational structures, depends primarily on the effective management of the flow of information. So, with the development of information and communication technology requirements of process automation is constantly increasing, because they are aimed at solving many problems, namely: digitization of paper documents; increases the speed of data retrieval; elimination of full or partial loss of information, inability to delay during data transfer from the server to the user, and the like.

Therefore, to solve these problems, as well as for productive economic, political, and social development of all spheres of Ukrainian society in general and educational sector in particular is required digitalization of educational systemsat all levels (from preschool education to prepare doctors of Sciences), which today is the main trend, which will provide entry into the European market of educational services and will promote the competitiveness of specialists in the labour market.

Analyzing legal documents for the development of the education sector in Ukraine, found out that the priority of the Ministry of education and science in the field of "Development potential of higher education" in 2020 identified the digitalization of higher education, in other words, the implementation 
of processes digitalization in all structures of the institution. However, in the framework of this priority envisages the introduction of innovative teaching methods, namely: open learning, flexible learning, blended learning that will contribute to the improvement of educational content, will provide a high level of training of future teachers in institutions of higher education in the field of adult education, and aims to stable development of formal and informal education at the state level.

A. Kharkivska noted that the improvement of educational content and the use of research and information technology training should occur in such areas of priority:

1. The creation of a common information technology training for a variety of academic disciplines oriented on information support of various forms of training activities.

2. Adopt NIT, development of new components of teaching methods, the creation of in formation-education a 1 environment in specific academic disciplines, will allow to consider possible changes in the state system of children's learning and to make adjustments in the learning process.

3 . The creation of domainspecific information and educational learning environments, allowing the use of technology integrated views of information and knowledge using hypermedia, multimedia systems, e-books and the like. These environments allow the integration of all known pedagogical software tools, and implement the idea of innovative approach to creation and use of new information technologies in education.

4. The use of computer network technology, the exchange of various information between users, to access databases, library collections, resources, major research centers and the like. With the development of computer technology and global information networks is increasingly evident the need for developing students ' knowledge, skills and navigation skills in information and educational space with the aim of improving their cognitive and practical activities in the conditions of informational society [6].

After analyzing the conclusions made by the researcher note that it is introduction in educational process the network information and communication technologies for the exchange of various information between users in modern conditions it is foggy technology.

The fuzzy technology is related to the fact that today the integration of network technology in most of the electronic (digital) devices, which until recently was not associated with network features (household appliances (digital thermometers, work pilesosi, humidifiers, etc.), industry (quadrocopter), personal devices (smart watches, fitness bracelets, smart phones, curtaphoneetc)).

Analyzing scientificpedagogical and professional literature revealed that this area is becoming increasingly popular, because these techniques are aimed at simplifying access to information, because it is placed closer to the users, and the elaboration and application of this information is placed on the outer nodes of the network, not in the cloud (cloud technology).

To understand the essence of the concept "foggy technology", in our view it is appropriate to relate it to the term "cloud" (cloud technology), which became the subject of research. Bykova, M. Zhaldak, N. Morse, S. Litvinova, A. Spirin, S. Semerkova, Y. Trius, A. Kharkivska, Is. Hricova and others.

Cloudtechnology is a radically new service that allows you to remotely use the tools of processing and storage $[4$, p. $99-$ $100]$.

Having analysed scientific works of V. Bykov [2, p. 7], we can state that these technologies should be aimed at meeting the educational needs of applicants education through the design, development, organization and implementation in the process of preparing e-learning courses (along with traditional); an electronic educational resources (EER) for educational purposes and computer-based systems of evaluation of educational achievements (obtaining assessments that complement traditional); social networking for educational purposes (to support the open ICT learning environment in collaboration); electronic portfolio organization and teaching assignments (reflect the character of educational activity of participants of educational process);innovative pedagogical technologies (components of computer-oriented methodical systems of learning that help to teach and learn new) [, p.7].

To date, the educational and administrative activities use of innovative technologies (cloudy oriented) in institutions of higher education takes on a global scale, so for example Google is actively working on the improvement of existing and the development and release of new cloud technologies (applications and services).

In the cloud model, the primary functions are performed by centralized data centers that collect data from the far nodes of the network and find them a further application. Clouds containing millions of terabytes of information, all have IT giants: Apple, Google, Intel and others. In the cloud model a lot of things depends on the bandwidth of the channels through which information is exchanged between the cloud and the periphery. According to the authors of the idea of fog computing, the transfer of a significant part of this work "in place" will increase the speed of decision-making. Centralized "cloud" and decentralized "fog" do not exclude each other but rather complement.

Misty technology is aimed at solving many problems, namely: high network latency; the difficulties with the movement of the extreme nodes of the network; loss of connection; the high cost propose strip; unpredictable network congestion; a huge geographical raspodele systems and customers [5].

In the "fog" - fog technology is the concept of drops. "Drop is a microcontroller chip with built-in memory and a data interface connected to a wireless chip of the Mesh format. Drops can be connected various sensors such as temperature, light, voltage" [3].

In 2012, F. Bona and others in 
the article, "Fog computing and its role in the Internet of things" for the first time described the phenomenon of foggy calculations [1, p. 13-16].

Fog computing is "a platform with a high level of virtualization, which includes computing services, information storage services, as well as network services between end devices and cloud computing centers, not necessarily located at the extreme levels of the network" [1, p. 1316.]

The paradigm of fog computing is different from computing the "fog" on the following parameters [3]: 1) at the end point computing device drops provides information about the position and data transmission is performed through small response delay in the network; 2) the geographical distribution of the components. Distribution services in Fog Computing is less centralized than the clouds, and separate devices can be linked through data flows and to share the heavy services. Geographic distribution is achievable by modern protocols for wireless sensor networks due to the relay protocols included in them; 3) a large amount of external data. Using the device equipped with many sensors, it is possible in realtime to generate huge amounts of data. Complex topology. Millions of geographically distributed nodes can be connected using various pre-defined communication; 4) mobility and heterogeneity. Mobility devices involves the use of alternative protocols, such as LISP; 5) the distribution of computing power in real time. Significant computing resources can be placed on the edge of the network, and should not be dependent on the coordinates of the place where the device is, and provide real-time assumes low latency when communicating to the same in Fog Computing may be the combination of the two systems have existed for a long time independently from each other; 6) Greatly simplifies the operation and administration of mobile devices - current and the load on them is growing rapidly, and using misty Abilene is possible to significantly accelerate the delivery of needed data on smartphones and to have comprehensive control over their work and, for example, to determine the location of the employee (student) at corporate fog with any desired accuracy; 7) interaction with other types of networks and interconnections. Through the use of bridges wireless sensor networks well, but due to the lack of a common standard protocols network this feature is currently not used fully.8) support the computation on the nodes and the relationship with the cloud. At the moment there are some difficulties with unification of distributed computing nodes and their relationship with the cloud [3].

In connection with the above, we note that foggy computing omits informationfrom the cloud to processitat the extreme levels of the network, which can significantly reduce the burden on it, increase the response time of the devices, and the like, and for these calculations does not require a connection to the Internet, as devices that do foggy calculations can operate autonomously, while receiving the necessary data from the external environment.

Thus, summing up all of the above, we can conclude that foggy computing is by no means a replacement for cloud technology, but rather a continuation of the ideas of preserving and processing information flows. Thanks to the drops, which is the basis of computing data, it becomes possible to isolate data in cloud systems and store them next to the user. Considering this aspect, it becomes possible to understand how localization of data facilitates the activities of persons engaged in the distribution of the data. In the concept of fog computing, cloud technology, greatly enhance its positive impact on the digitalization of the educational process.

Based on the analysis of scientific and pedagogical and special literature, namely the conclusions made by leading scientists, as well as taking into account their own experience in higher education, we consider it appropriate to create and operate an educational and scientific laboratory that will address the implementation and use of innovative (cloud and foggy) technologies in the educational process of HEI.

Employees of the educational and scientific laboratory of innovative technologies in their activities must be guided by the Laws of Ukraine "On Education", "On Higher Education", the Charter of higher education, as well as other legal documents governing educational, methodological and scientific activities.

The purpose of this laboratory is: to promote the quality of training of students, research and teaching staff on the use of cloud and fog technologies in the management of educational institutions, training and professional activities, etc; formulation and solution of urgent problems regarding the introduction of cloud and fog technologies in the educational process, development of necessary for the educational process educational, methodical, scientific materials in accordance with current and promising areas of management, educational and scientific activities of higher education, administration, research and teaching staff, students (students, graduate students, doctoral students), etc.

The main tasks and functions of the educational-scientific laboratory of innovative technologies should be: the organization and carrying out laboratory, seminars, practical and lecture classes for subjects of educational process in high educational, scientific, methodological and technical levels; planning, organizing, coordinating and conducting scientific research in accordance with the plan of research work of HEI, faculty, department, etc; constant updating of scientific and methodological support of the laboratory, and, as a consequence, the improvement of the processes of informatization of educational process as well as the introduction and improvement of electronic document management of institutions of higher education, faculty, department, etc; monitoring the availability of training and methodological support of disciplines taught in the institution of higher education and for the timely updating and completing the electronic funds of 
the library, faculty, department, educational, educational and methodical manuals, methodical recommendations, methodical instructions, workshops, collections of tasks and other tests, etc.; organization of extracurricular independent work of subjects of educational process to develop their logical thinking, creativity, creativity, soft skills(sometimes flexible skills); maintenance of an individual approach regarding the work of the scientific-pedagogical and teaching staff with students through a consultation using cloud and misty of innovative technologies; creation of corresponding organizationalpedagogical conditions for the completion of qualification of workers of other educational institutions.

Thus, the use of foggy technologywill improve the management of higher education institutions, improving of educational process of training future specialists and specialties for which training is call, and advanced training for scientific-pedagogical and pedagogical workers of the educational institution.

Prospects of further scientific search is seen in the introduction to the work of higher education institutions educational-scientific laboratory of innovative technologies to test the effectiveness of the misty technologies.

In connection with the above, we note that the vague calculation, is lowered from the cloud to information processing at the extreme levels of the network.

\section{REFERENCES}

1. Bonomi, F., Milito, R., Zhu, J., Addepalli, S. (2012). Fog computing and its role in the internet of things. Proceedings of the first edition of the MCC workshop on Mobile cloud computing.

2. Bykov, V. Yu. Innovatsiinyi rozvytok zasobiv i tekhnolohii system vidkrytoi osvity. Suchasni informatsiini tekhnolohii ta innovatsiini metodyky u pidhotovtsi fakhivtsiv: metodolohiia, teoriia, dosvid, problemy. Kyiv-Vinnytsia : TOV firma "Planer".
3. Zhaldak, A. V. Operatyvna obrobka danykh za dopomohoiu vykorystannia tumannykh tekhnolohii. Retrieved from http:// compi.com.ua/operativnaobrobkadanih-za-dopomogoyuvikoristannya-tumannih.html

4. Lytvynova, S. H. (2013). Khmarni tekhnolohii v upravlinni doshkilnymy navchalnymy

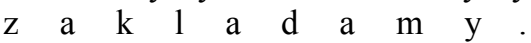
Ynformatsyonnokompiuternble tekhnolohyy v эkonomyke, obrazovanyy y sotsyalnoisfere. Vир. 8, 99-101.

5. Machek Krants. Tumannue vuchyslenyia spuskaiut oblachnui funktsyonal na zemliu. Retrieved from https://www.cisco.com/c / about/press/press-releases/2015/ 08-13d.html

6. Kharkivska, A. A. (2014). Analiz shliakhiv udoskonalennia zmistu profesiinoi pidhotovky maibutnoho vchytelia informatyky. Aktualni problemy derzhavnoho upravlinnia, pedahohiky ta psykholohii, 172-174.

Стаття надійшла 17.03.2020 p. 